Attp:/www.journals.zu.edu.eg/journalDisplay.aspx?Journalld=1\&queryType=Master

\title{
PRODUCTIVE AND REPRODUCTIVE TRAITS IMPROVEMENT OF THE EGYPTIAN LOCAL STRAIN RABBITS BY THE CROSSING WITH TWO FOREIGN STRAINS
}

\author{
Mohamed D. Mahran ${ }^{1}$, A.E. Nasr ${ }^{1}$, Soliman I. Peris ${ }^{1}$ and A.M. Alzohairy ${ }^{2}$ \\ 1. Anim. Prod. Dept., Fac. Agric., Zagazig Univ., Egypt \\ 2. Genet. Dept., Fac. Agric., Zagazig Univ., Egypt
}

Received: 16/10/2017 ; Accepted: 08/11/2017

\begin{abstract}
The numbers of 1317 parities were analyzed to evaluate crossing effects among three breeds of rabbits. The tested breeds were New-Zealand White (NZW), Chinchilla (Ch) and Gabali (G). An incomplete dialed crossing mating design excluding the two reciprocal crosses between the two foreign breeds ( $\left.{ }_{+} \mathrm{Chx}{ }^{\Uparrow} \mathrm{NZW},+\mathrm{NZWx}{ }^{\Uparrow} \mathrm{Ch}\right)$ was adopted. The traits studied were litter size (LS) at birth (LSB), litter size at 21 days (LS21) and litter size at weaning (LSW), litter weight (LW) at birth (LWB), litter weight at 21days (LW21) and litter weight at weaning (LWW). As well as, growth traits involved: individual body weight (BW) at 4 (BW4), 6 (BW6), 8 (BW8), 10 (BW10) and 12 (BW12) weeks of age. In addition, heterosis $\left(\mathrm{H}^{\mathrm{I}}\right)$ was estimated for all traits studied. Effect of mating type was significant $(\mathrm{P}<0.05)$ for LS, LW and BW traits. In purebreeds, $\mathrm{G}$ rabbits recorded the highest value of each $(\mathrm{P}<0.05) \operatorname{LSB}, \operatorname{LS} 21$ and $\operatorname{LSW}(7.3,5.9$, and 5.8, respectively). In crossbreed, results showed that ${ }^{\circ} \mathrm{Gx}{ }^{\lambda} \mathrm{Ch}$ recorded the highest value of each LSB, LS21 and LSW (7.5, 6.1, and 5.9, respectively). With respect to LW traits, in purebred rabbits, G recorded the highest LWB (411.9 g), while NZW recorded the highest LW21 and LWW (1745.4 and 2824.4 g, respectively). In crossbreeds, $\oplus \mathrm{Gx} \widehat{\top} \mathrm{Ch}$ showed the highest LWB (394.2 g), while + NZW x ${ }^{\lambda} \mathrm{G}$ recorded the highest LW21 and LWW (1836.5, 2917.1 g, respectively). + New Zealand White $\mathrm{x}$ G Gabali rabbits and +Chx ${ }^{\lambda} \mathrm{G}$ rabbits recorded negative and non-significant estimates of heterosis (\%) for LS and LW traits. Individual body weight traits were significantly influenced by mating type during the different

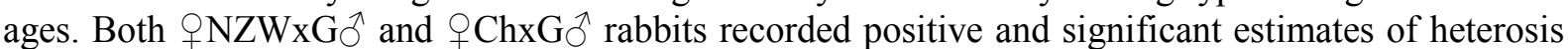
(\%) for BW traits. Based on the results of the present study, it could be concluded that crossing between $\mathrm{G}$ does and Ch bucks improved LS and/or LW traits. Also, crossing between G bucks and NZW does improved growth traits, LWB and LW21.
\end{abstract}

Key words: Rabbits, litter size, gabali, crossbreeding, growth traits, heterosis.

\section{INTRODUCTION}

Rabbits are characterized as a small body size compared to other domestic animals. Moreover, does produce 30 to 40 young a year and these are sold at 2.2 to $2.4 \mathrm{~kg}$ at about 80 days (Lebas et al., 1997). Rabbit meat is easier to digest and tastier than other meat types that are commonly consumed (Dronca et al., 2013). Traits such as LS, LW and BW and DG are very important economic traits for meat production (Garcia et al., 2006).

Crossbreeding is an effective means of changing the genetic of animal and exploiting genetic variation between populations (Ragab et al., 2016). Crossbred litters obtained from mating G bucks with NZW doe were higher than those litters obtained from the back crossing (Khalil and Afifi, 2000). Moreover, significant positive estimates of $\mathrm{H}^{\mathrm{I}}$ for $\mathrm{LS}$ and $\mathrm{LW}$ at birth

\footnotetext{
* Corresponding author: Tel. : +201094851170

E-mail address: m.mahran@zu.edu.eg
} 
and weaning were found (Khalil and Afifi, 2000). Many studies found that LSB, LSW, LWB and LWW for purebred or crossbred Gabali does were higher than those observed in Bouscat and Ch (Afifi, 1971; Afifi and Emara, 1989) and NZW rabbits (Khalil and Afifi, 2000).

Growth traits are important factors which affect the profitability of meat production (Soliman et al., 2014). Also, body weight is an important economic character in the commercial rabbit industry. In this respect, numerous studies (Afifi et al., 2000; Khalil and Afifi, 2000; Saleh et al., 2005) found that BW improved by the crossing between local breeds and other standard breeds (e.g. NZW, Californian ... etc.). Also, El-Bayomi et al. (2012) found that crossing of Californian $(\mathrm{Ca})$ males with NZW females improve BW due to heterotic effect. On the other hand, Afifi and Emara (1988) found that crossing among Bouscat, Giza White, White Flander and Baladi Red, decreased BW of crossbred groups at 5 to 12 weeks of age.

Therefore, the present study aimed to evaluate some productive and reproductive traits for seven genotypes of rabbits including $\mathrm{G}$ as a local breed, NZW and $\mathrm{Ch}$ rabbits as foreign breeds and their crosses under Egyptian conditions.

\section{MATERIALS AND METHODS}

The experience was held at a private farm located about $60 \mathrm{~km}$ from Zagazig, Sharkia Governorate, Egypt (from 2014 to 2016). Rabbits were obtained from the farm Faculty of Agriculture, Zagazig University, Egypt. The study was carried out on three pure breeds of rabbits, local breed Gabali (G), New-Zeland White (NZW) and Chinchilla (Ch). For the purebreds, ten does and three bucks were used. While, for the crossbreds, fifteen does and four bucks from each breed were used. Three breeds dialed crossed design was constructed as presented in Table 1. As shown in Table 1, ${ }_{+} \mathrm{Chx}{ }^{\lambda} \mathrm{NZW}$ and ${ }_{+} \mathrm{NZWx}{ }^{\lambda} \mathrm{Ch}$ were absent because our aim was to evaluate $G$ and their crosses.

Rabbits were housed under uniform conditions of management in hutches measuring (60 $\mathrm{cm}$ length, $60 \mathrm{~cm}$ width and $40 \mathrm{~cm}$ height) provided with manual feeder and a nipple system for watering. Metal nest box $(40 \mathrm{x} 40 \mathrm{x}$ $40 \mathrm{~cm})$ was attached to the doe's cage. Litters were weaned at 4 weeks of age. Lighting was available for a period of 14 hours/day throughout the experimental period. Rabbits were fed on commercial pelleted diets with the following characteristics: $18 \%$ crude protein, $13-14 \%$ crude fibers, $2400-2600 \mathrm{kcal} / \mathrm{kg}$ diet digestible energy.

Each doe was inserted to the buck's cage for mating. Doe, buck's number and date of mating were recorded. Each doe palpated for pregnancy 10 days after service. The expected date of kindling is recorded, for positively palpated does. While negative ones were remitted. On the $28^{\text {th }}$ day of gestation, cleaning and installation of kindling box for mothers before kindling 4-5 days. Assessment of the litter, just after kindling was carried out and dead kits were taken away. Moreover, litter size, born alive and born dead was also recorded from birth until weaning at 4 weeks of age.

Heterosis $\left(\mathrm{H}^{\mathrm{I}}\right)$ for all traits studied were estimated according to Dickerson theory (Dickerson, 1992). Such genetic model permits to derive a selected set of linear contrasts as for flowing:

$\mathrm{H}^{\mathrm{I}}$ in units $=[(\mathrm{NZW} \times \mathrm{G}+\mathrm{G} \times \mathrm{NZW})-(\mathrm{NZW} \times$ $\mathrm{NZW}+\mathrm{G} \times \mathrm{G})] / 2$

$\mathrm{H}^{\mathrm{I}}$ in units $=[(\mathrm{Ch} \times \mathrm{G}+\mathrm{G} \times \mathrm{Ch})-(\mathrm{Ch} \times \mathrm{Ch}+\mathrm{G} \times$ G)] $/ 2$

$\mathrm{H}^{\mathrm{I}}(\%)=[(\mathrm{NZW} \times \mathrm{G}+\mathrm{G} \times \mathrm{NZW})-(\mathrm{NZW} \times \mathrm{NZW}$ $+\mathrm{G} \times \mathrm{G})] /[\mathrm{NZW} \times \mathrm{NZW}+\mathrm{G} \times \mathrm{G}](100)$.

$\mathrm{H}^{\mathrm{I}}(\%)=[(\mathrm{Ch} \times \mathrm{G}+\mathrm{G} \times \mathrm{Ch})-(\mathrm{Ch} \times \mathrm{Ch}+\mathrm{G} \times \mathrm{G})] /$ $[\mathrm{Ch} \times \mathrm{Ch}+\mathrm{G} \times \mathrm{G}](100)$.

Where $\mathrm{H}^{\mathrm{I}}$ heterosis in units.

\section{Statistical Analysis}

Statistical analysis was performed by means of the PROC GLM procedure of SAS (SAS, 2002). The Significance of the difference between the means was verified by Duncan's new multiple ranges test (Duncan, 1955). Using the following model:

$$
\mathrm{Y}_{\mathrm{ijklmn}}=\mu+\mathrm{B}_{\mathrm{i}}+\mathrm{D}_{\mathrm{ij}}+\mathrm{C}_{\mathrm{j}}+\mathrm{S}_{\mathrm{l}}+\mathrm{P}_{\mathrm{m}}+\mathrm{e}_{\mathrm{ijk} \mathrm{m} n}
$$


Table 1. Number of bucks, does and bunnies distributed in the seven mating types of the study

\begin{tabular}{|c|c|c|c|c|}
\hline Mating type & Bucks & Does & Bunnies born & Bunnies weaned \\
\hline GxG & 3 & 10 & 913 & 739 \\
\hline NZWXNZW & 3 & 10 & 897 & 719 \\
\hline ChxCh & 3 & 10 & 757 & 667 \\
\hline$q \mathbf{G} \mathbf{x}^{\lambda} \mathbf{N Z W}$ & 4 & 15 & 1432 & 1210 \\
\hline$\uparrow \mathbf{G} \mathbf{x} \overbrace{}^{\lambda} \mathbf{C h}$ & 4 & 15 & 1413 & 1239 \\
\hline$\uparrow \mathbf{N Z W} \mathbf{x} \overbrace{}^{\lambda} \mathbf{G}$ & 4 & 15 & 1248 & 1031 \\
\hline$\uparrow \mathbf{C h x} \overbrace{}^{\lambda} \mathbf{G}$ & 4 & 15 & 1240 & 1060 \\
\hline Total & 25 & 90 & 8066 & 6790 \\
\hline
\end{tabular}

Where:

$Y_{\mathrm{ijklmn}}$ is the observation on the ijklmn the litter and growth traits (LSB, LS21, LSW, LWB, LW21, LWW, .....etc.); $\mu$ is the overall mean; $B_{i}$ is the fixed effect of $i^{\text {th }}$ breed group; $D_{i j}$ is the random effect of $j^{\text {th }}$ doe nested within the $i^{\text {th }}$ breed group; $C_{k}$ is the fixed effect of $k^{\text {th }}$ year of kindling $(\mathrm{k}=1,2) ; \mathrm{S}_{1}$ is the fixed effect of the $1^{\text {th }}$ season of kindling $(1=1,2,3,4)$; $\mathrm{P}_{\mathrm{m}}$ is the fixed effect of $\mathrm{m}^{\text {th }}$ parity $(1=1,2, \ldots ., 5)$; and $\mathrm{e}_{\mathrm{ijk} k \mathrm{mn}}$ is the random error term.

\section{RESULTS AND DISCUSSION}

\section{Litter Size and Litter Weight Traits}

Mating type had significant $(\mathrm{P}<0.05$ or $\mathrm{P}<$ $0.01)$ effect on LS and LW traits as shown in Table 2. These results agree with those reported by Galal and Khalil (1994), Iraqi et al. (2010) and Hassanien and Baiomy (2011). It was observed that mating type effect was significant on LSB, LS at 14 days, LSW, LWB, LW at 14 days and LWW (Hassanien and Baiomy, 2011). Moreover, Iraqi et al. (2010) found that mating type had a significant $(\mathrm{P}<0.05)$ effect on LSW and LWW in a crossbreeding experiment between NZW and G breeds. Conversely, mating type had non-significant effect on LSB alive and LWB alive (Iraqi et al., 2010).

Interestingly, $\mathrm{G}$ rabbits recorded the highest values of LSB, LS21 and LSW compared to NZW and Ch rabbits. On the other hand, Ch rabbits recorded the lowest estimates of LSB, LS21 and LSW. Differences in LSB between breeds and/or between does within breed could be due to the differences in uterine capacity, conception rate, or the differences in maternal effect between breeds and between does within the breeds and determined by the number of mature, fertilized and established ova (Argente et al., 2003; Gad-Alla et al., 2005; Nofal et al., 2005; Pannu et al., 2005).

Gabali rabbits had the highest $(\mathrm{p}<0.05)$ estimate of LWB, while the NZW rabbits had the highest estimate of LW21 and LWW (Table 2). Khalil et al. (1995) found that NZW purebred had larger LS and heavier LW than the Baladi Red rabbits. Interestingly, Khalil (1994) found that NZW rabbits were higher in milk production and maternal ability compared with the local breeds; this could be the main cause of the poor performance for the local breeds.

As shown in Table 2, mating type had significant effects $(\mathrm{p}<0.05$ or $\mathrm{p}<0.01)$ on LS and LW traits. Crossbred ${ } \mathrm{Gx}{ }^{\lambda} \mathrm{Ch}$ rabbit had higher LSB, LS21 and LSW compared to the other crossbreds. While ${ }^{+} \mathrm{Chx}{ }^{\lambda} \mathrm{G}$ rabbits recorded the lowest estimates for all LS traits and LWB and LWW (Table 2). On the other hand, $+\mathrm{Gx}{ }^{\lambda} \mathrm{Ch}$ rabbits showed the highest $(\mathrm{p}$ $<0.05$ ) estimate of LWB. While $9 \mathrm{NZWx}{ }^{\lambda} \mathrm{G}$ rabbits recorded the highest estimates of LW21 and LWW. The superiority of crossbred LS and LW traits could be due to hybrid vigor which 
Mahran, et al.

Table 2. Least square means and tests of significance for litter traits and heterosis of NZW, Ch and $G$ pure breeds and their crossing during the experimental period

\begin{tabular}{|c|c|c|c|c|c|c|}
\hline \multirow{2}{*}{$\begin{array}{l}\text { Mating type } \\
\left(\uparrow \times{ }^{\Uparrow}\right)\end{array}$} & \multicolumn{3}{|c|}{ LS at } & \multicolumn{3}{|c|}{ LW (g) } \\
\hline & Birth & 21 days & Weaning & Birth & 21 days & Weaning \\
\hline$\overline{\mathrm{NZW} \times \mathrm{NZW}}$ & $7.03 \pm 0.19^{\mathrm{a}}$ & $5.78 \pm 0.15^{\mathrm{ab}}$ & $5.62 \pm 0.15^{\mathrm{ab}}$ & $350.71 \pm 9.36^{c}$ & $1745.44 \pm 42.56^{b}$ & $2824.47 \pm 68.55^{\mathrm{a}}$ \\
\hline $\mathbf{C h} \times \mathbf{C h}$ & $6.55 \pm 0.16^{\mathrm{b}}$ & $5.45 \pm 0.13^{b}$ & $5.39 \pm 0.14^{\mathrm{b}}$ & $350.09 \pm 594^{\mathrm{c}}$ & $1548.14 \pm 24.83^{\mathrm{c}}$ & $2553.36 \pm 42.90^{b}$ \\
\hline $\mathbf{G} \times \mathbf{G}$ & $7.36 \pm 0.18^{\mathrm{a}}$ & $5.96 \pm 0.15^{\mathrm{a}}$ & $5.87 \pm 0.15^{\mathrm{a}}$ & $411.99 \pm 7.61^{\mathrm{a}}$ & $1560.92 \pm 24.73^{\mathrm{c}}$ & $2586.44 \pm 36.75^{\mathrm{b}}$ \\
\hline $\mathbf{N Z W} \times \mathbf{G}$ & $7.01 \pm 0.17^{\mathrm{a}}$ & $5.94 \pm 0.15^{\mathrm{a}}$ & $5.76 \pm 0.14^{\mathrm{ab}}$ & $374.59 \pm 7.33^{\mathrm{b}}$ & $1836.53 \pm 47.01^{\mathrm{a}}$ & $2917.09 \pm 58.84^{\mathrm{a}}$ \\
\hline $\mathbf{C h} \times \mathbf{G}$ & $5.70 \pm 0.10^{\mathrm{c}}$ & $4.93 \pm 0.10^{c}$ & $4.64 \pm 0.10^{\mathrm{c}}$ & $310.0 \pm 5.19^{d}$ & $1399.34 \pm 22.36^{a}$ & $2346.72 \pm 33.16^{\mathrm{c}}$ \\
\hline $\mathbf{G} \times \mathbf{N Z W}$ & $7.19 \pm 0.13^{\mathrm{a}}$ & $5.79 \pm 0.12^{\mathrm{ab}}$ & $5.60 \pm 0.12^{\mathrm{ab}}$ & $365.97 \pm 6.22^{b c}$ & $1546.77 \pm 21.19^{c}$ & $2580.12 \pm 36.39^{b}$ \\
\hline $\mathbf{G} \times \mathbf{C h}$ & $7.54 \pm 0.23^{\mathrm{a}}$ & $6.06 \pm 0.12^{\mathrm{a}}$ & $5.99 \pm 0.13^{\mathrm{a}}$ & $394.25 \pm 6.33^{\mathrm{a}}$ & $1589.23 \pm 23.28^{\mathrm{c}}$ & $2650.30 \pm 36.04^{\mathrm{b}}$ \\
\hline Sig & $* *$ & $*$ & $* *$ & $* *$ & $* *$ & $* *$ \\
\hline \multicolumn{7}{|c|}{ Heterosis } \\
\hline $\begin{array}{l}\mathbf{H}_{\text {Sig }}^{\mathrm{I}(\mathrm{NEW}-\mathrm{G})} \\
\end{array}$ & $-0.10 \pm 0.32$ & $-\underset{\text { NS }}{-0.005 \pm 0.48}$ & $\begin{array}{c}-0.07 \pm 0.46 \\
\text { NS }\end{array}$ & $\underset{\mathrm{NS}}{-11.07 \pm 19.26}$ & $\underset{\mathrm{NS}}{38.47 \pm 134.0}$ & $43.15 \underset{\mathrm{NS}}{ \pm 164.84}$ \\
\hline H\% & -1.32 & -0.09 & -1.13 & -2.90 & 2.33 & 1.59 \\
\hline$\underset{\text { Sig }}{\mathbf{H}^{\mathrm{I}}(\mathbf{C H}-\mathrm{G})}$ & $\begin{array}{c}-0.34 \pm 0.35 \\
\text { NS }\end{array}$ & $-\underset{\mathrm{NS}}{-0.21 \pm 0.43}$ & $-\underset{\mathrm{NS}}{-0.32 \pm 0.41}$ & $\begin{array}{c}-28.92 \pm 17.74 \\
\text { NS }\end{array}$ & $\underset{\text { NS }}{-60.25 \pm 106.40}$ & $-\underset{\mathrm{NS}}{-71.39 \pm 131.47}$ \\
\hline H\% & -4.82 & -3.68 & -5.60 & -7.59 & -3.88 & -2.78 \\
\hline
\end{tabular}

- Least square means \pm S.E in the same column within bearing different superscripts differ significantly at $\mathrm{P}<0.05$.

- Values are significant at $* \mathrm{P}<0.05 ; * * \mathrm{P}<0.01 ; * * * \mathrm{P}<0.001$

- NS = Not-significant

- LSB= Litter size at birth; LS21 = litter size at 21days; LSW=litter size at weaning; LWB =litter Weight at birth; LW21 = litter Weight at 21days; LWW= litter Weight at weaning; NZW= New Zealand White rabbits; Ch = Chinchilla rabbits; $\mathrm{G}=$ Gabali; $\mathrm{H}^{\mathrm{I}}=$ heterosis.

showed in different ages of kits (Rashwan et al., 1995; Abdel-Azeem et al., 2007). Ragab et al. (2016) stated that, crossing can improve LS traits in rabbits.

Table 2 showed that estimates of $\mathrm{H}^{\mathrm{I}}$ were negative and not significant for all LS and LW traits. The negative values $\mathrm{H}^{\mathrm{I}}$ for the traits studied may be more due to some higher means in the local $G$ breed than in the foreign NZW and Ch breeds (Khalil and Afifi, 2000). Crossing of $\mathrm{G}$ with NZW rabbits was associated with significant positive estimates of $\mathrm{H}^{\mathrm{I}}$ for $\mathrm{LSB}$, LWB and LWB, LWW (Khalil and Afifi, 2000). Therefore, our results and other study (Ragab and Baselga, 2011) suggest that commercial rabbit producers utilize breeds selected for the traits of economic interest rather than on a popular breed.

\section{Growth performance}

Table 3 presents the effect of mating type of (NZW), (Ch) and (G) breeds on growth traits in different age periods. Results showed that mating type had significant $(\mathrm{P}<0.05$ or $\mathrm{p}<$ $0.01)$ effect on post-weaning growth traits as shown in Table 3. Purebred (NZW) recorded the highest values of BW4, BW6, BW8, BW10 and BW12. While $(G)$ rabbits recorded the lowest values of BW4, BW6 and BW8. Moreover, Ch rabbits recorded the lowest values of BW10 and BW12 compared to other purebreds. In crossbreeding experiment carried out in Egypt, and using NZW and Baladi Black, Abdel-Ghany et al. (2000) observed that, the effect of mating type was generally significant for weaning and post-weaning BW traits. 
Table 3. Least square means and tests of significance for individual body weight (g) traits and heterosis of NZW, Ch and G pure breeds and their crossing during the experimental period

\begin{tabular}{|c|c|c|c|c|c|}
\hline \multirow{2}{*}{$\begin{array}{l}\text { Mating type } \\
\left(Q^{\prime} \times{ }^{\lambda}\right)\end{array}$} & \multicolumn{5}{|c|}{ body weight (g) } \\
\hline & BW4 & BW6 & BW8 & BW10 & BW12 \\
\hline$\overline{\mathrm{NZW} \times \mathrm{NZW}}$ & $516.43 \pm 11.14^{\mathrm{ab}}$ & $933.41 \pm 13.11^{\mathrm{a}}$ & $1328.91 \pm 15.26^{\mathrm{a}}$ & $1714.11 \pm 17.03^{\mathrm{a}}$ & $2049.22 \pm 14.49^{\mathrm{bc}}$ \\
\hline $\mathrm{Ch} \times \mathrm{Ch}$ & $504.63 \pm 9.68^{b c}$ & $843.61 \pm 8.99^{c}$ & $1204.69 \pm 8.66^{\mathrm{d}}$ & $1549.86 \pm 9.35^{\mathrm{c}}$ & $1927.01 \pm 8.33^{\mathrm{e}}$ \\
\hline $\mathbf{G} \times \mathbf{G}$ & $462.62 \pm 7.64^{\mathrm{d}}$ & $812.14 \pm 5.01^{\mathrm{d}}$ & $1181.9 \pm 6.40^{\mathrm{d}}$ & $1564.44 \pm 6.39^{c}$ & $1940.95 \pm 6.55^{\mathrm{e}}$ \\
\hline $\mathbf{N Z W} \times \mathbf{G}$ & $535.14 \pm 9.32^{\mathrm{a}}$ & $938.49 \pm 10.53^{\mathrm{a}}$ & $1343.41 \pm 12.08^{\mathrm{a}}$ & $1743.85 \pm 12.73^{\mathrm{a}}$ & $2143.30 \pm 17.06^{\mathrm{a}}$ \\
\hline $\mathbf{C h} \times \mathbf{G}$ & $533.0 \pm 7.09^{\mathrm{a}}$ & $886.61 \pm 8.93^{\mathrm{b}}$ & $1262.78 \pm 9.45^{\mathrm{c}}$ & $1646.52 \pm 10.28^{b}$ & $2024.49 \pm 10.30^{c}$ \\
\hline G× NZW & $529.95 \pm 7.36^{\mathrm{a}}$ & $880.14 \pm 7.48^{\mathrm{b}}$ & $1296.23 \pm 8.9^{b}$ & $1671.72 \pm 8.07^{\mathrm{b}}$ & $2070.05 \pm 8.19^{\mathrm{a}}$ \\
\hline $\mathbf{G} \times \mathbf{C h}$ & $464.83 \pm 6.28^{\mathrm{d}}$ & $825.46 \pm 6.05^{\mathrm{cd}}$ & $1205.46 \pm 6.18^{\mathrm{d}}$ & $1565.80 \pm 9.27^{\mathrm{c}}$ & $1980.63 \pm 6.66^{\mathrm{d}}$ \\
\hline Sig & $* *$ & $* *$ & $* *$ & $* *$ & $* *$ \\
\hline \multicolumn{6}{|c|}{ Heterosis } \\
\hline $\begin{array}{l}\mathbf{H}^{\mathbf{I}(\text { (NEW-G) }} \\
\text { Sig }\end{array}$ & $\underset{*}{43.02 \pm 12.10}$ & $36.54 \pm 13.83$ & $64.42_{* *}^{ \pm 15.05}$ & $68.51 \pm 16.21$ & $\underset{* *}{111.59 \pm 14.36}$ \\
\hline & 8.79 & 4.19 & 5.13 & 4.18 & 5.59 \\
\hline$\underset{\text { Sig }}{\mathbf{H}^{\mathrm{I}} \text { (CH-G) }}$ & $\underset{* *}{15.29 \pm 8.56}$ & $\underset{* *}{28.16 \pm 8.13}$ & $40.82 \pm 8.72$ & $49.01 \pm 11.02$ & $\underset{\mathrm{NS}}{68.58 \pm 10.23}$ \\
\hline$\underline{\mathbf{H} \%}$ & 3.16 & 3.40 & 3.42 & 3.15 & 3.55 \\
\hline
\end{tabular}

- Least square means \pm S.E in the same column within bearing different superscripts differ significantly at $\mathrm{P}<0.05$.

- Values are significant at $* \mathrm{P}<0.05 ; * * \mathrm{P}<0.01 ; * * * \mathrm{P}<0.001 \quad$ - NS $=$ Not-significant

- Growth traits: BW4 = body weight at 4 weeks; BW6 = body weight at 6 weeks; BW8 = body weight at 8 weeks; BW10 = body weight at 10 weeks; BW12 = body weight at 12 weeks; $\mathrm{H}^{\mathrm{I}}=$ heterosis.

Results in Table 3 show that ${ }_{+} \mathrm{NZWx} \bigcirc^{\lambda} \mathrm{G}$ crossbred recorded the highest $(\mathrm{p}<0.05)$ values of BW4, BW6, BW8, BW10 and BW12. While, $\mathrm{Gx}^{\lambda} \mathrm{Ch}$ crossbred recorded the lowest values of BW6, BW8, BW10 and BW12. From these results, it is clear that the $\$ \mathrm{NZWx}{ }^{-} \mathrm{G}$ hybrid surpassed the ${ }^{2} \mathrm{Chx}{ }^{\lambda} \mathrm{G}$ hybrid for BW traits. The obtained results partially agree with the findings reported by Youssef (1992), Afifi et al. (1994), Abdel-Ghany et al. (2000) and Abou Khadiga et al. (2008).

Crossbreds $+\mathrm{NZWx} \mathrm{x}^{\lambda} \mathrm{G}$ showed high positive $\mathrm{H}(\%)$ for BW4, BW6, BW8, BW10 and BW12 (Table 3 ). In this respect, crossbreds line $\mathrm{v}$ x local Baladi showed positive heterosis for BW (Abou-Khadiga, 2004; Attalah, 2006). Furthermore, direct heterosis for $\mathrm{BW}$ were mainly positive and ranged from 1.3 to $14.5 \%$ (Khalil and Bolet, 2010). Also, Abdel-Ghany et al. (2000) and Afifi et al. (1994) found that heterosis (\%) ranged from 2.7 to $9.5 \%$ for postweaning BW by crossing NZW with Baladi Black or Baladi Red in Egypt. Moreover, ElBayomi et al. (2012) found that CaxNZW rabbits recorded positive and high estimates of heterosis for BW.

\section{Conclusions}

Since LS, LW and growth traits in NZW and $G$ rabbits were not significantly different in their breed performance. Moreover, LS traits improved as a result of crossing $\mathrm{G}$ does with $\mathrm{Ch}$ bucks. Also, LW and growth traits improved when NZW does were crossed with Gabali bucks. All these results suggest, the importance of using $G$ rabbits as a paternal or a maternal line in crossing with the foreign breeds to improve the productive and reproductive performance of rabbits under Egyptian conditions.

\section{REFERENCES}

Abdel-Azeem, S., A.M. Abdel-Azim, A.A. Darwish and E.M. Omar (2007). Body weight and carcass traits in four pure breeds of rabbits and their crosses under Egyptian environmental conditions. $5^{\text {th }}$ Int. Conf. Rabbit Prod. in Hot Climate, Hurghada, Egypt, 67-80. 
Abdel-Ghany, A.M., E.G. Ahmed and N.S. Hassan (2000). Crossbreeding genetic parameters of post-weaning growth traits of the Egyptian acclimatised New Zealand White and native Baladi Black rabbits. In $7^{\text {th }}$ World Rabbit Cong., Valencia, Spain, A : 317-323)

Abou Khadiga, G.S.M. (2004). Performance of the Spanish synthetic line (V) and the local Baladi Black rabbits and their crosses under Egyptian conditions (Doctoral dissertation, M. Sc. Thesis, Fac. Agric., Kafr El-Sheikh, Tanta Univ., Egypt.

Abou Khadiga, G., K. Saleh, R. Nofal and M. Baselga (2008). Genetic evaluation of growth traits in a crossbreeding experiment involving line $\mathrm{V}$ and Baladi Black rabbits in Egypt. $9^{\text {th }}$ World Rabbit Cong., June 10-13, VeronaItaly, 23-27.

Afifi, E.A. (1971). A study of some economical and productive characters in some strains of rabbits and their crosses. Ph.D. Thesis, Fac. Agric., Ain Shams Univ., Egypt.

Afifi, E.A. and M.E. Emara (1988). Postweaning viability of purebred and crossbred rabbits under Egyptian conditions. J. Appl. Rabbit Res., 11 (1): 38-41.

Afifi, E.A. and M.E. Emara (1989). Analysis of litter size in rabbits in a diallel crossbreeding scheme involving four local Egyptian and exotic breeds. J. Appl. Rabbit Res., 12: 256258.

Afifi, E.A., M.H. Khalil, A.F. Jhadr and Y.M.K. Youssef (1994). Heterosis, maternal and direct effects of post-weaning growth traits and carcass performance in rabbit crosses. J. Anim. Breed Genet., 111 : 138-147.

Afifi, E.A., N.Z. Bedier and S.M. Gad (2000). Genetic components of crossbreeding for growth and livability traits in Gabali, Californian rabbits and their crosser under Semi Arid conditions. In Proc. $3^{\text {rd }}$ All Afr. Conf. Anim. Agric. and $11^{\text {th }}$ Conf. Egypt. Soc. Anim. Prod., 6-9.

Argente, M.J., M.A. Santacreu, A. Climent and A. Blasco (2003). Relationships between uterine and fetal traits in rabbits selected on uterine capacity. J. Anim. Sci., 81 (5): 12651273.
Attalah, G.E.Y. (2006). Crossbreeding effects of progeny traits due to crossing of Bauscat and Baladi Red rabbits. J. Agric. Sci. Mansoura Univ., $31:$ 7549-7559.

Dickerson, G.E. (1992). Experimental approaches in utilizing breed resources. In Anim. Breed. Abst., 37 (19): 191 - 202.

Dronca, D., P. Nicolae, B. Ioan, B. Marian, P. Razvan, C. Ada and G. Daniela (2013). Comparative research regarding the average efficiency at slaughter of the pure breeds fellows, F1 simple hybrids (ㅇ NZW $\mathrm{x}^{\lambda}$ CHL) and of the double three-breeds hybrids ( $9 \mathrm{~F} 1 \mathrm{x}^{\lambda} \mathrm{CAL}$ ) of Oryctolagus Cunicullus. Sci. Papers Anim. Sci. and Biotechnol., 46 (2): 84-87.

Duncan, D.B. (1955). Multiple Range and Multiple F tests. Biomet., 11: 1- 42.

El-Bayomi, K.M., M.S. El-Tarabany and T.M. Abdel-Hamid (2012). Estimation of heterosis and combining ability for some weaning and post-weaning traits in three different breeds of rabbits. J. Ame. Sci., 8 (9): 282-288.

Gad Alla, S.A.Z., M.A. Abo Warda and S.Z. Meshreky (2005). Reproductive performance, litter traitsand milk production of Baladi Red, V-line rabbits breeds and their crosses under Egyptian environmental conditions. Egypt. J. Rabbit Sci., 15: 45 - 61.

Galal, E.S.E. and M.H. Khalil (1994). Development of rabbit industry in Egypt. Cahiers Options Mediterraneennes (CIHEAM).

Garcia, T., J. Sanchez, O. Rafel, J. Ramon and M. Piles (2006). Heterosis direct and maternal genetic effects on semen quality traits of rabbits, Livestock Sci., 100 : 111120.

Hassanien, H.H.M. and A.A. Baiomy (2011). Effect of breed and parity on growth performance, litter size, litter weight, conception rate and semen characteristics of medium size rabbits in hot climates. Egypt Poult. Sci. J., 31-45.

Iraqi, M.M., M.E. Shenana and M. Baselga (2010). Some factors affecting production and milk composition characters in a crossbreeding experiment involving Gabali 
and V-line rabbits in Egypt. World Rabbit Sci., 15 (3): 151-159.

Khalil M.H. (1994). Lactational performance of Giza White rabbits and its relation with preweaning litter traits. Anim. Prod, 59:141145.

Khalil, M.H., EA. Afifi, Y.M.K. Youssef and A.F. Khadr (1995). Heterosis, maternal and direct genetic effects for litter performance and reproductive intervals in rabbit crossers. World Rabbit Sci., 3 (3): 99-105.

Khalil, M.H. and E.A. Afifi (2000). Heterosis, maternal and direct additive effects for litter performance and post weaning growth Gabali rabbits and their F1 crosses with New Zealand White. $7^{\text {th }}$ World Rabbit Congs.

Khalil, M.H. and G. Bolet (2010). Sustainable rabbit breeding and genetic improvement programs achieved in developing countries. In Proc. $9^{\text {th }}$ World Cong. on Genet. Appl. Livestock Prod., August 1-6, 2010, Leipzig, Germany Communication, 962.

Lebas, F., P. Coudert, R. Rouvier and H. De Rochambeau (1997). The Rabbit: husbandry, health, and production. Rome: Food and Agric. Organ. of the United Nations.

Nofal, R., K. Saleh, H. Younis and G. AbouKhadiga (2005). Evaluation of Spanish synthetic line V, Baladi Black rabbits and their crosses under Egyptianconditions.1. Litter size. In: Proc. $4^{\text {th }}$ Int. Conf. Rabbit Prod. Hot Climates, 24-27 Feb., Sharm ElSheikh, Egypt, 23 - 29.

Pannu, U., B.K. Beniwal, V.K. Singh and R.S. Gahlot (2005). Reproductive performance and economical value of does in different broiler breeders of rabbit under semiarid conditions. Indian J. Anim. Sci., 75:425 428.

Ragab, M. and M. Baselga (2011). A comparison of reproductive traits of four maternal lines of rabbits selected for litter size at weaning and founded on different criteria. Livestock Sci., 136 (2): 201-206.

Ragab, M., J.P. Sanchez, C. Minguez and M. Baselga (2016). Crossbreeding effects on rabbit reproduction from four maternal lines of rabbits. Anim., 10 (7): 1086-1092.

Rashwan, A.A., S.S. Ahmed and M.I. Tawfeek (1995). Doe reproduction and preweaning and postweaning litter performance of straightbred and crossbred rabbits. J. Agric. Sci., Mansoura Univ., Egypt, 20:2839 -2851.

Saleh, K., R. Nofal, H. Younis and G. Abou Khadiga (2005). Evaluation of line V, Baladi Black rabbits and their crosses under Egyptian conditions. 2. Litter weight and mean kit weight. In: Proc. $4^{\text {th }}$ Int. Conf. Rabbit Prod. Hot Climates, 24-27 Feb., Sharm El-Sheikh, Egypt, 31- 37.

SAS (2002). Statistical Analysis System, SAS User's Guide Statistics, SAS Institute Inc., Editions Cary NC.

Soliman, H.A.M., S.M.A. Gad and I.M. Ismail (2014). Genetic parameters for post-weaning growth traits of Gabali rabbits in Egypt. Egyptian Poult. Sci. J., 34 :2.

Youssef, M.K. (1992). Productive performance of purebred and crossbred rabbits. M.Sc. Thesis, Fac. Agric. at Moshtohor, Zagazig Univ., Banha Branch, Egypt. 
تحسين الصفات الإتتاجية والتتاسلية لسلالة الأرانب المصرية المحلية بواسطة التهجين مع سلالتين أجنبيتين

محمد ديدامونى مهران' - عبدالمجيد السيد نصر' ـ سليمان إبراهيم السيد برس' ـ أحمد منصور الزهيرى'

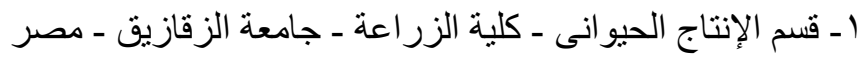

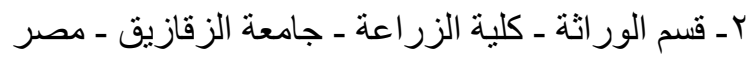

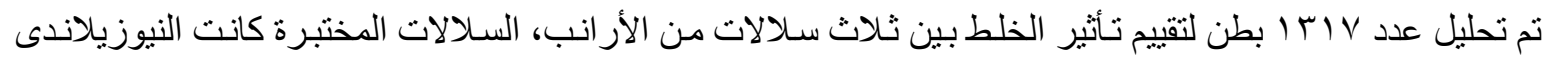

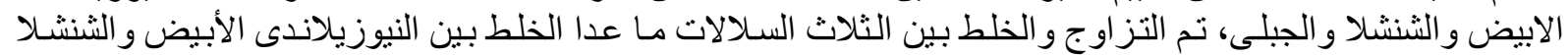

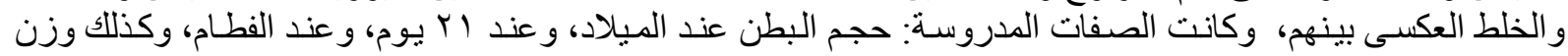

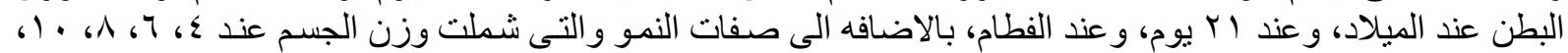

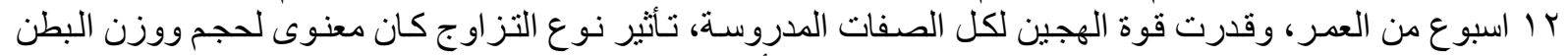

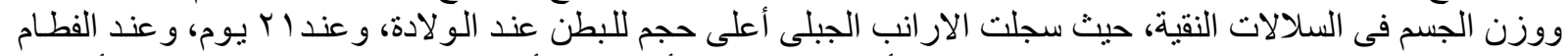

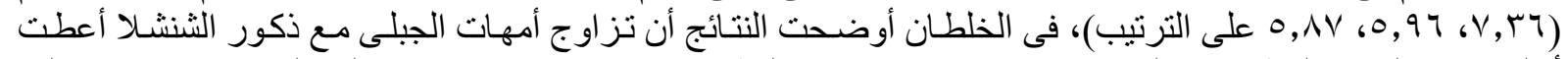

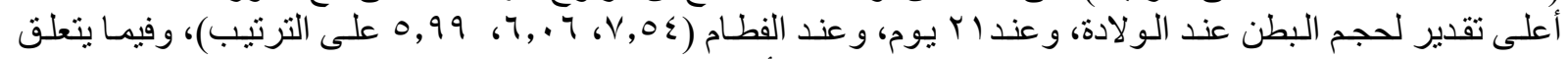

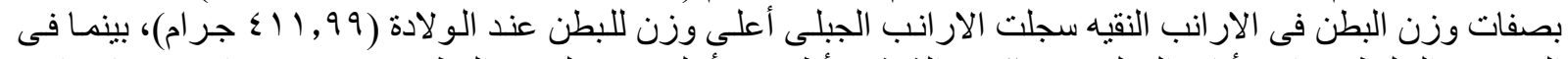

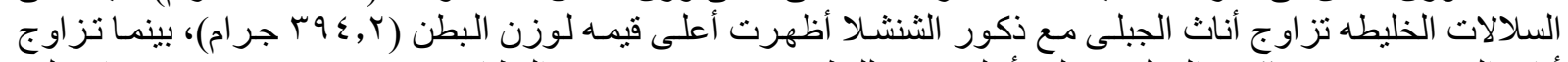

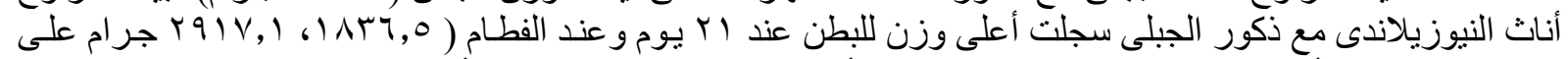

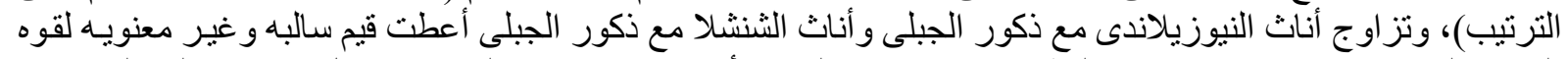

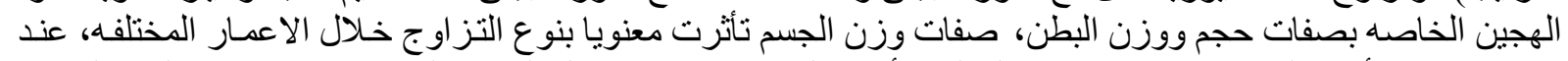

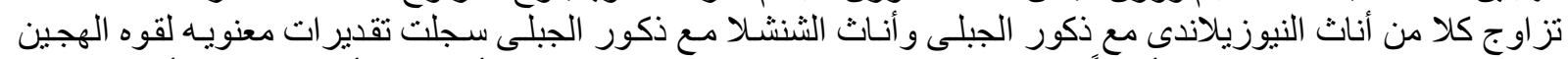

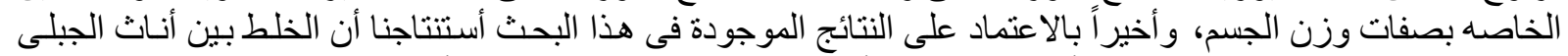

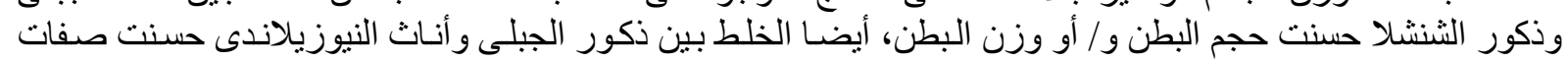

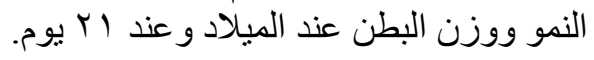

